\title{
A Facile Route to Triazole Dendrimers via Click Chemistry Linking Tripodal Acetylene and Dendrons
}

\author{
Jae Wook Lee* and Byung-Ku Kim \\ Department of Chemistry, Dong-A University, Hadan-2-dong, Busan 604-714, Korea. *E-mail: jlee@dau.ac.kr \\ Received January 20, 2005
}

Key Words : Click chemistry, Cycloaddition, Dendrimers, 1,2,3-Triazoles

\begin{abstract}
Dendrimers are highly branched macromolecules, which are prepared by repetition of a given set of reactions using either divergent or convergent strategies. ${ }^{1}$ Generally, the reactions employed are high yielding without any side reactions. Well known processes, such as the Michael reaction, Williamson ether synthesis, amidations and reductions have been used extensively. ${ }^{2}$ Recent investigation of the click chemistry, the $\mathrm{Cu}(\mathrm{I})$-catalyzed Huisgen $[2+3]$ dipolar cycloaddition reaction between an organic azide and an alkyne, has attracted attention which has found many applications in organic chemistry, ${ }^{3}$ supramolecular chemistry, ${ }^{4}$ drug discovery, ${ }^{5}$ bioconjugations, ${ }^{6}$ and materials science. ${ }^{7}$ The reaction is characterized by very high yields, mild and simple reaction conditions, oxygen and water tolerance, and ease of product isolation. It is highly chemoselective affording only the desired 1,2,3-triazole even in the presence of a large variety of other functional groups. ${ }^{8}$ There are few reports to synthesize the triazole-mediated dendritic materials using click chemistry. ${ }^{9}$ Due to our interest in developing new dendrimers, ${ }^{10}$ we became involved in exploring efficient click reaction. Herein we present the convergent synthesis of triazole dendrimers by the trimerization reaction of Fréchettype azido-dendrons via click chemistry using trispropagyl amine as a tripodal core.
\end{abstract}

\section{Experimental Section}

General procedure for the preparation of 1,2,3-triazole dendrimers 3-Gn by reaction between tripropargylamine 1 and azido-dendrons 2-Dn. A mixture of tripropargylamine 1 (0.05 mmol) and azido-dendrons 2-Dn $(0.15 \mathrm{mmol})$ in $\mathrm{DMF}-\mathrm{H}_{2} \mathrm{O}(4: 1)$ in the presence of $5 \mathrm{~mol} \% \mathrm{CuSO}_{4} \cdot 5 \mathrm{H}_{2} \mathrm{O}$ with 10 mol \% sodium ascorbate was stirred at 50-60 ${ }^{\circ} \mathrm{C}$. The reaction was monitored by TLC regarding on the disappearance of 2-Dn and the generation and disappearance of mono- and/or di-triazole derivatives. The mixture was cooled to room temperature and then normal workup was carried out. The desired product was isolated by column chromatography.

3-G1: $93 \%$ yield; ${ }^{1} \mathrm{H}$ NMR $\left(300 \mathrm{MHz}, \mathrm{CDCl}_{3}\right) \delta 3.71$ (s, $6 \mathrm{H}), 3.75$ (s, 18H), 5.42 (s, 6H), 6.39 (br, 9H), 7.67 (s, 3H); ${ }^{13} \mathrm{C}$ NMR (75 MHz, $\left.\mathrm{CDCl}_{3}\right): \delta 161.2,144.2,136.9,123.7$, 105.8, 100.3, 55.3, 54.0, 47.1; MS (FAB): $\mathrm{m} / z 710.8\left[\mathrm{M}^{+}\right]$; HRMS (FAB) calcd for $\mathrm{C}_{36} \mathrm{H}_{42} \mathrm{~N}_{10} \mathrm{O}_{6}:$ 710.3289. found: 710.3282 .
3-G2: $88 \%$ yield; ${ }^{1} \mathrm{H}$ NMR $\left(500 \mathrm{MHz}, \mathrm{CDCl}_{3}\right) \delta 3.72(\mathrm{~s}$, $6 \mathrm{H}), 3.75(\mathrm{~s}, 36 \mathrm{H}), 4.90(\mathrm{~s}, 12 \mathrm{H}), 5.37(\mathrm{~s}, 6 \mathrm{H}), 6.38(\mathrm{~m}, 6 \mathrm{H})$, $6.47(\mathrm{~m}, 6 \mathrm{H}), 6.53(\mathrm{~m}, 15 \mathrm{H}), 7.66(\mathrm{~s}, 3 \mathrm{H}) ;{ }^{13} \mathrm{C} \mathrm{NMR}(125$ $\left.\mathrm{MHz}, \mathrm{CDCl}_{3}\right): \delta 161.1,161.09,161.07,161.02,160.97$, $160.96,160.4,144.4,138.9,137.0,123.8,107.1,105.2$, 102.1, 100.0, 70.1, 55.48, 55.46, 55.45, 55.43, 55.37, 55.32, 55.3, 55.29, 55.27, 54.1, 47.3; MS (FAB): $m / z$ 1527.5 [M+]; HRMS (FAB) calcd for $\mathrm{C}_{84} \mathrm{H}_{90} \mathrm{~N}_{10} \mathrm{O}_{18}: 1526.6435$. found: 1526.6338.

3-G3: $42 \%$ yield; ${ }^{1} \mathrm{H}$ NMR (500 MHz, $\left.\mathrm{CDCl}_{3}\right) \delta 3.70(\mathrm{~s}$, $6 \mathrm{H}), 3.75(\mathrm{~s}, 72 \mathrm{H}), 4.86(\mathrm{~s}, 12 \mathrm{H}), 4.92(\mathrm{~s}, 24 \mathrm{H}), 5.34(\mathrm{~s}, 6 \mathrm{H})$, $6.38(\mathrm{~m}, 12 \mathrm{H}), 6.42(\mathrm{~m}, 6 \mathrm{H}), 6.50-6.55(\mathrm{~m}, 33 \mathrm{H}), 6.61(\mathrm{~m}$, $12 \mathrm{H}), 7.63(\mathrm{~s}, 3 \mathrm{H}) ;{ }^{13} \mathrm{C}$ NMR $\left(125 \mathrm{MHz}, \mathrm{CDCl}_{3}\right): \delta 161.0$, $160.3,160.1,144.4,139.1,138.9,137.0,123.8,107.0$, 106.4, 105.3, 105.0, 102.1, 101.7, 99.9, 70.0, 55.3, 54.0, 47.3; MS (FAB): $m / z 3161.7\left[\mathrm{M}^{+}\right]$; HRMS (FAB) calcd for $\mathrm{C}_{180} \mathrm{H}_{186} \mathrm{~N}_{10} \mathrm{O}_{42}$ : 3159.2726. found: 3159.2754.

\section{Results and Discussion}

The synthetic strategy for triazole dendrimers 3-Gn utilized a convergent method using the tripodal acetylenes $\mathbf{1}$ and the Fréchet-type azido-dendrons 2-Dn (Scheme 1). The Fréchet-type azido-dendrons 2-Dn $(\mathrm{n}=1,2$, and 3: generation of dendron, Figure 1) were prepared according to the reported procedure. ${ }^{11}$

To probe the effectiveness for the construction of the triazole dendrimer 3-Gn via the 1,3-dipolar cycloaddition reactions of the tripodal acetylene 1 and azido-dendrons 2Dn, we simply utilized the click chemistry condition, which is well-documented. The active $\mathrm{Cu}(\mathrm{I})$ species, generated in situ by reacting $5 \mathrm{~mol} \% \mathrm{CuSO}_{4} \cdot 5 \mathrm{H}_{2} \mathrm{O}$ with $10 \mathrm{~mol} \%$

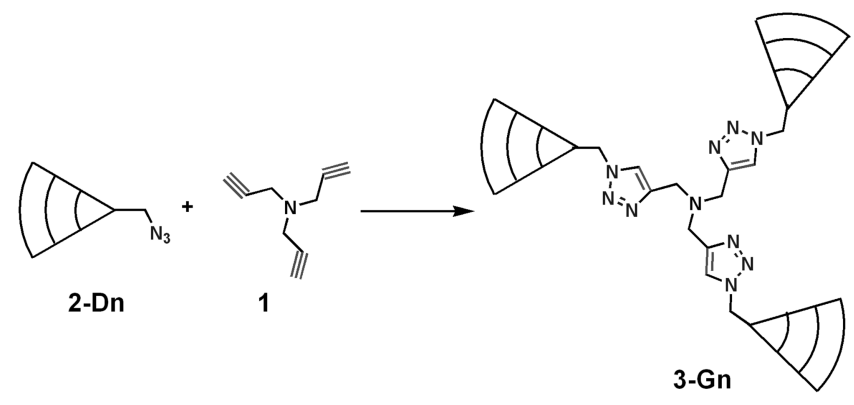

Scheme 1. Synthetic strategies of triazole dendrimers by trimerization. 


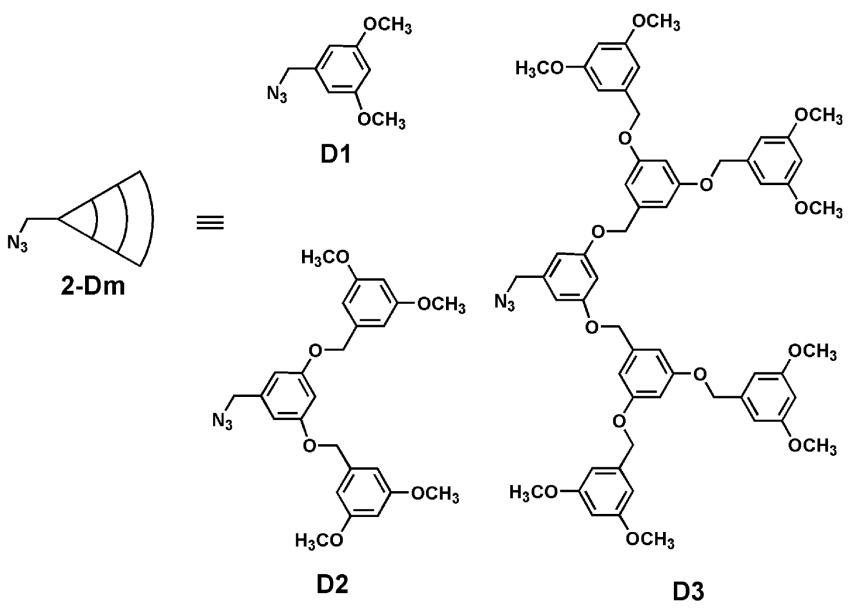

Figure 1. Structures of azido-dendrons.

sodium ascorbate as the reducing agent, provide the 1,4disubstituted 1,2,3-triazole in excellent yield. ${ }^{12}$

We carried out the reactions in a $4: 1$ solvent ratio of DMF to $\mathrm{H}_{2} \mathrm{O}$ using $5 \mathrm{~mol} \% \mathrm{CuSO}_{4} \cdot 5 \mathrm{H}_{2} \mathrm{O}$ with $10 \mathrm{~mol} \%$ sodium ascorbate at $50-60{ }^{\circ} \mathrm{C}$. The reaction could be checked by IR spectroscopy by following the disappearance of the $\mathrm{N}_{3}$ stretching band at around $2100 \mathrm{~cm}^{-1}$. The generation and disappearance of the intermediates, which are mono- and/or di-triazole derivatives, were monitored by TLC runs of the reaction mixture. The reaction of tripropargylamine 1 with 2-D1 in $0.09 M$ solution provided the triazole dendrimer 3G1 having just 1,4-disubstituted 1,2,3-triazole units in yield of $93 \%$ after $12 \mathrm{~h}$. For the second generation dendrimer, the reaction of trispropagyl amine $\mathbf{1}$ with 2-D2 in $0.06 \mathrm{M}$ solution provided the triazole dendrimer $\mathbf{3 - G 2}$ in $81 \%$ yield after $12 \mathrm{~h}$, which went up to $88 \%$ in $24 \mathrm{~h}$. The reaction of trispropagyl amine $\mathbf{1}$ with 2-D3 in $0.02 M$ solution afforded the triazole dendrimer 3-G3 in $40-42 \%$ after $24 \mathrm{~h}$. It was also found that the reaction in $0.1 \mathrm{M}$ solution provided the desired product in around $42 \%$ yield. We do not understand the reasons to get at low yield even though we do not observe any side product(s). We just suspect not to recover completely from silica-gel column chromatography. However we could not rule out the steric hindrance and/or spatial congestion of nitrogen core and dendron. We plan to investigate this further by changing the tripodal core component. Therefore, the results showed that the formation of triazole between tripodal acetylene and azido-dendrons can be regarded as a new connector to construct various dendrimers and functional materials.

All compounds were confirmed by ${ }^{1} \mathrm{H}$ and ${ }^{13} \mathrm{C}$ NMR spectroscopy and FAB mass spectra. From their ${ }^{1} \mathrm{H}$ NMR spectra $\left(\mathrm{CDCl}_{3}\right)$, the peaks of the methylene protons adjacent to the nitrogen core and the triazole protons in dendrimers 3-Gn were found at 3.71 and $7.67 \mathrm{ppm}$ for 3-G1, 3.72 and $7.66 \mathrm{ppm}$ for 3-G2, and 3.70 and $7.63 \mathrm{ppm}$ for 3G3 (Figure 2), respectively. There are no characteristic differences according to the dendrimer generations.

In summary, we have demonstrated that the trimerization reactions between tripodal acetylene and azido-dendrons

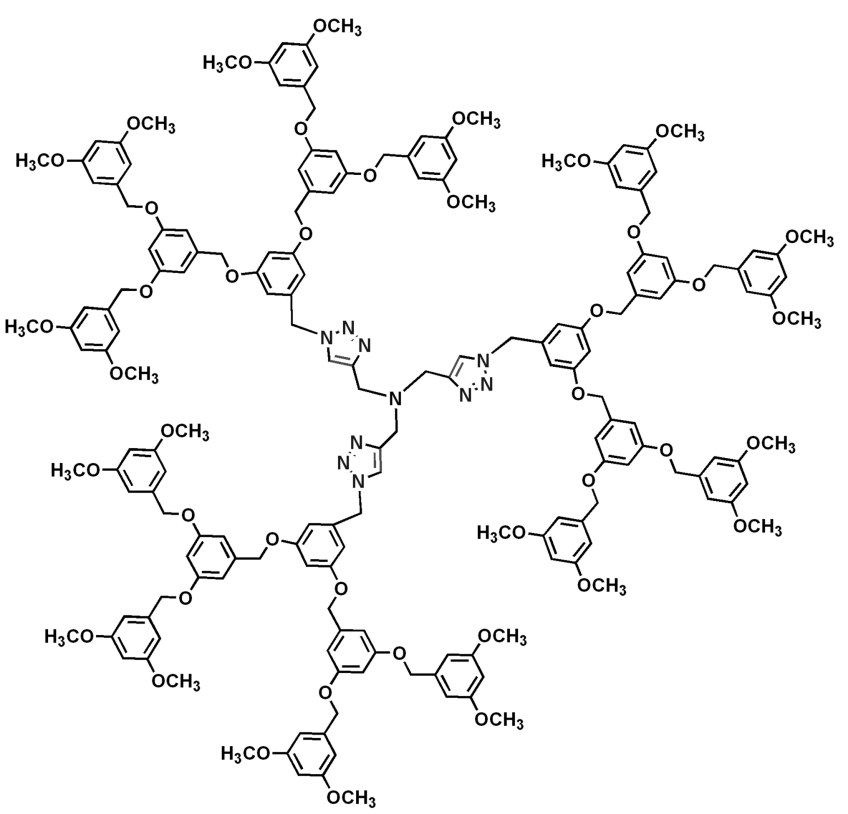

Figure 2. Structure of the third generation of triazole dendrimer 3G3.

lead to the formation of 1,4-disubstituted triazole dendrimers. This unique reaction may then provide an insight into designing various symmetrical dendrimers. We are currently working towards various functional dendrimers using this strategy for various applications, such as the templated synthesis of nanomaterials.

Acknowledgement. This research was supported by the MIC (Ministry of Information and communication), Korea, under the ITRC (Information Technology Research Center) support program supervised by the IITA (Institute of Information Technology Assessment). We thank Prof. S. Samal for reading the manuscript.

\section{References and Notes}

1. Grayson, S. M.; Fréchet, J. M. J. Chem. Rev. 2001, 101, 3919.

2. (a) Newkome, G. R.; Moorefield, C. N.; Vögtle, F. Dendrimers and Dendrons: Concepts, Synthesis, Applications; Wiley-VCH: Weinheim, 2001. (b) Fréchet, J. M. J.; Tomalia, D. A. Dendrimers and Other Dendritic Polymers; John Wiely \& Sons Ltd.: 2001. (c) Choi, J. S.; Choi, Y. H.; Park, J. S. Bull. Korean Chem. Soc. 2004, 25, 1025. (d) Kim, T.-i.; Jang, H.-s.; Joo, D. K.; Choi, J. S.; Park, J.-S. Bull. Korean Chem. Soc. 2003, 24, 123.

3. (a) Katritzky, A. R.; Zhang, Y.; Singh, S. K. Heterocycles 2003, 60, 1225. (b) Wang, Z.-X.; Qin, H.-L. Chem. Commun. 2003, 2450. (c) Jin, T.; Kamijo, S.; Yamamoto, Y. Eur. J. Org. Chem. 2004, 3789 .

4. (a) Badjiæ, J. D.; Balzani, V.; Credi, A.; Lowe, J. N.; Silvi, S.; Stoddart, J. F. Chem. Eur. J. 2004, 10, 1926. (b) Lee, J. K.; Chi, Y. S.; Choi, I. S. Langmuir 2004, 20, 3844. (c) Collman, J. P.; Devaraj, N. K.; Chidsey, C. E. D. Langmuir 2004, 20, 1051. (d) Chi, Y. S.; Lee, J. K.; Lee, K.-B.; Kim, D. J.; Choi, I. S. Bull. Korean Chem. Soc. 2005, 26, 361.

5. (a) Lenda, F.; Guenoun, F.; Tazi, B.; larbi, N. B.; Martinezd, J.; Lamaty, F. Tetrahedron Lett. 2004, 45, 8905. (b) Manetsch, R.; Krasiñski, A.; Radiæ, Z.; Raushel, J.; Taylor, P.; Sharpless, K. B.; 
Kolb, H. C. J. Am. Chem. Soc. 2004, 126, 12809. (c) Kolb, H. C.; Sharpless, K. B. Drug Discovery Today 2003, 8, 1128.

6. (a) Wang, Q.; Chan, T. R.; Hilgraf, R.; Fokin, V. V.; Sharpless, K. B.; Finn, M. G. J. Am. Chem. Soc. 2003, 125, 3192. (b) Meng, J.c.; Siuzdak, G.; Finn, M. G. Chem. Commun. 2004, 2108. (c) Link, A. J.; Vink, M. K. S.; Tirrell, D. A. J. Am. Chem. Soc. 2004, 126, 10598. (d) Sivakumar, K.; Xie, F.; Cash, B. M.; Long, S.; Barnhill, H. N.; Wang, Q. Org. Lett. 2004, 6, 4603 and references therein.

7. Díaz, D. D.; Punna, S.; Holzer, P.; McPherson, A. K.; Sharpless, K. B.; Fokin, V. V.; Finn, M. G. J. Polym. Sci., Part A 2004, 42, 4392.

8. Kolb, H. C.; Finn, M. G.; Sharpless, K. B. Angew. Chem. Int. Ed. 2001, 40, 2004

9. (a) Wu, P.; Feldman, A. K.; Nugent, A. K.; Hawker, C. J.; Scheel,
A.; Voit, B.; Pyun, J.; Fréchet, J. M. J.; Sharpless, K. B.; Fokin, V. V. Angew. Chem. Int. Ed. 2004, 43, 3928. (b) Helms, B.; Mynar, J. L.; Hawker, C. J.; Fréchet, J. M. J. J. Am. Chem. Soc. 2004, 126, 15020. (c) Wuytswinkel, G. V.; Verheyde, B.; Compernolle, F; Toppet, S.; Dehaen, W. J. Chem. Soc., Perkin Trans. 1 2000, 1337. 10. Lee, J. W.; Kim, B.-K.; Jin, S. H. Bull. Korean Chem. Soc. submitted.

11. Desai, A.; Atkinson, N.; Rivera, F., Jr.; Devonport, W.; Rees, I.; Branz, S. E.; Hawker, C. J. J. Polym. Sci., Part A 2000, 38, 1033.

12. (a) Rostovtsev, V. V.; Green, L. G.; Fokin, V. V.; Sharpless, K. B. Angew. Chem. Int. Ed. 2002, 41, 2596. (b) Tornøe, C. W.; Christensen, C.; Meldal, M. J. Org. Chem. 2002, 67, 3057. (c) Fazio, F.; Bryan, M. C.; Blixt, O.; Paulson, J. C.; Wong, C.-H. J. Am. Chem. Soc. 2002, 124, 14397. 